\title{
First record of filamentous fungi in the coastal upwelling ecosystem off central Chile
}

\section{Primer registro de hongos filamentosos en el ecosistema de surgencia costero frente a Chile central}

\author{
Marcelo H. Gutiérrez ${ }^{1,4 *}$, Silvio Pantoja ${ }^{2,4}$, Renato A. Quiñones ${ }^{2,4}$ \& Rodrigo R. GonzÁlez ${ }^{3}$ \\ ${ }^{1}$ Programa de Postgrado en Oceanografía, Departamento de Oceanografía, Universidad de Concepción, Chile. \\ 2Departamento de Oceanografía y Centro de Investigación Oceanográfica en el Pacífico Sur-Oriental, Universidad de \\ Concepción, Chile. \\ ${ }^{3}$ Programa de Biotecnología Marina, Facultad de Ciencias Naturales y Oceanográficas, Universidad de Concepción, Chile. \\ ${ }^{4}$ Programa de Investigación Marina de Excelencia, PIMEX-Nueva Aldea, Facultad de Ciencias Naturales y Oceanográficas, \\ Universidad de Concepción, Chile.
}

*Email: magutier@udec.cl

\begin{abstract}
We report for the first time the presence of filamentous fungi in the water column and sediment in the coastal upwelling ecosystem off central Chile, using molecular tools and epifluorescence microscopy. Positive amplifications of SSU 18s rDNA with specific fungal primers were obtained for surface waters and sediments of this coastal ecosystem. Molecular richness obtained from denaturing gradient gel electrophoresis showed a higher number of fungal genotypes in nearshore than offshore sites and in summer than winter. Fungal structures identified by epifluorescence microscopy in the water column were present as individual filaments or as aggregates of hyphae. We show for the first time vertical water column profiles of fungal biomass in the marine ecosystem. Fungal biomass reached up to $5 \mu \mathrm{g} \mathrm{C} \mathrm{L}^{-1}$ in surface waters during summer and their vertical patterns agreed with those of chlorophyll- $a$ and with the general distribution of microplankton biomass in the ocean. The presence of viable fungi in the coastal ocean encourages us to decipher their role in the processing of marine organic matter and to evaluate their inclusion in the actual paradigm of the microbial loop and in the biogeochemistry of the oceans.
\end{abstract}

KeYwoRDs: Fungi, upwelling ecosystem, central south Chile.

\section{RESUMEN}

Este estudio reporta por primera vez la presencia de hongos filamentosos en la columna de agua y sedimentos del ecosistema de surgencia costero de Chile central. La detección de hongos fue realizada utilizando herramientas moleculares y microscopía de epifluorescencia. Productos de amplificación positivos del gen 18s rADN fueron obtenidos para muestras de agua y sedimento superficial de este ecosistema costero. El análisis de riqueza molecular de los productos de PCR, realizado por electroforesis en gel con gradiente denaturante, mostró un mayor número de genotipos de hongos en las estaciones más cercanas a la costa y durante el verano. Estructuras de hongos fueron identificadas por microscopía de epifluorescencia y fueron observadas como filamentos individuales o como agregados de hifas. Nuestros resultados muestran los primeros perfiles verticales de biomasa de hongos en el ecosistema marino. La biomasa de hongos alcanzó valores de hasta $5 \mu \mathrm{g} C$ $\mathrm{L}^{-1}$ en aguas superficiales durante el verano y su estructura vertical fue similar a la observada para clorofila- $a$ y consistente con la distribución vertical general descrita para la biomasa microplactónica en el océano. La presencia de hongos viables en el océano costero plantea la necesidad de descifrar su rol en el procesamiento materia orgánica y evaluar su incorporación en el paradigma actual del anillo microbiano y en los ciclos biogeoquímicos del océano.

Palabras clave: Hongos, ecosistema de surgencia, centro sur de Chile. 


\section{INTRODUCTION}

The Humboldt Current System off Chile is one the most productive marine ecosystems of the world, with annual primary production rates close to $1 \mathrm{~kg} \mathrm{C} \mathrm{m}^{2}$ (Daneri et

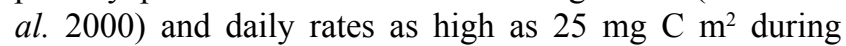
the productive season in the coastal upwelling area off Concepción (Montero et al. 2007). High productivity during austral spring and summer is fuelled by upwelling events (Daneri et al. 2000) that bring up cold waters with high nutrient concentration toward the ocean's surface. A major fraction of photosynthetic carbon produced in the Humboldt Current System off Chile is degraded by the microbial community (González et al. 1998, Troncoso et al. 2003, Cuevas et al. 2004, Montero et al. 2007). Most studies have attributed to bacteria the major role in processing organic matter in the microbial loop off central Chile (e. g. Troncoso et al. 2003, Cuevas et al. 2004). However, there is evidence that archaea are also responsible for an important fraction of microbial secondary production (Levipán et al. 2007, Quiñones et al. 2009).

A noticeable increase in lithogenic opal in the water column off Concepcion suggests an important input of terrigenous material during winter due to the discharge of the nearby Itata and Biobio rivers (Sánchez et al. 2009). The succession of upwelling and river discharge during the annual cycle and the drastic changes in environmental conditions (e.g. temperature, salinity, oxygen) (Cáceres \& Arcos 1991, Strub et al. 1998, Daneri et al. 2000, Figueroa \& Moffat 2000, Sobarzo et al. 2007), result in a heterogeneous environment with temporal changes in the quality and abundance of organic matter. This could sustain a diverse microbial community in this coastal upwelling ecosystem.

Fungi are important in terrestrial environments for their role in processing detrital organic matter from plants (Carlile $e t$ al. 2001) but have also been detected in several freshwater and coastal marine ecosystems (e. g. Hyde et al. 1998, Wong et al. 1998, Fell \& Newell 1998, Raghukumar 2005, Gulis et al. 2006, Gessner et al. 2007), where they could play a major role in the detrital food web (e. g. Hyde et al. 1998, Raghukumar et al. 2005). However, their role in processing marine organic matter and in the biogeochemical cycles in the ocean is poorly known, when compared with the terrestrial environment (Fell \& Newell 1998, Clipson 2006).

Here we report for the first time the presence of filamentous fungi in the marine ecosystem off central Chile and their spatial distribution in the water column and sediment. Although our analysis of the spatial and temporal distribution of fungi is preliminary, it strongly suggests that they are regular inhabitants of the upwelling ecosystem off Central
Chile, and that they play a biogeochemical role that we have begun to unravel.

\section{MATERIALS AND METHODS}

SAMPLING

The study was conducted in the coastal zone off central Chile, in the area adjacent to the discharge of the Itata river (Fig. 1), one the main rivers in central-southern Chile, with typical annual average runoffs of $300 \mathrm{~m}^{3} \mathrm{~s}^{-1}$ (Quiñones \& Montes 2001).

Seawater and marine sediments were sampled during three cruises conducted in the coastal zone adjacent to the Itata river discharge (Fig. 1) in austral winter and summer, onboard the R/V Kay Kay II. Additional water samples were collected in summer from a continental shelf oceanographic station located at $18 \mathrm{NM}$ from the coast of Concepción in central Chile (Fig. 1). Temperature, oxygen and chlorophyll- $a$ data at Station 18 were derived from the Time Series Coastal Station 18 (www.copas.udec.cl/eng/research/serie/) of the Center for Oceanographic Research in the eastern South Pacific (FONDAP-COPAS Center) of the University of Concepcion. Temperature and oxygen at Station A were obtained using CTDO casts (Seabird 19 plus) and chlorophyll- $a$ was determined by fluorometry (Parsons et al. 1984) in a Turner Designs ${ }^{\circledR}$ fluorometer.

The water column at Station A was sampled on August 3-4, 2007 (Winter) at $5,15,30,50,110 \mathrm{~m}$ depth and at $5 \mathrm{~m}$ in Station C, and during the Summer (December 16, 2008) at Station 18 (7, 30, 50, $80 \mathrm{~m}$ depth). Samples were collected with Niskin bottles and stored in sterile containers, which were protected from sunlight until they arrived to the laboratory. Water samples were filtered through $0.45 \mu \mathrm{m}$ sterile cellulose ester filters for molecular analyses ( $1 \mathrm{~L})$ and through $0.7 \mu \mathrm{m}$ glass fiber for chlorophyll- $a$ determination $(1 \mathrm{~L})$. Filters were stored in liquid nitrogen until processing. Aliquots of $50 \mathrm{~mL}$ seawater were poisoned with formaldehyde $(2 \%$ final concentrations) and stored $\left(4{ }^{\circ} \mathrm{C}\right.$ at darkness) for fungi epifluorescense detection and counting.

Surface sediment samples were collected with a modified Van Veen grab and stored in liquid nitrogen for molecular analysis. Surface sediment sampling was carried out at Stations B and C on August 16-18, 2006 (winter) and at Stations A, B, C on January 18-19 2007 (summer).

DNA EXTRACTION AND PCR AMPLIFICATION

DNA was extracted from the filters and sediments using the Power Soil DNA Kit (MO BIO Laboratories, Inc.). One $\mu \mathrm{L}$ of the template DNA from the sediments was subjected to 
standard PCR using fungal primers NS1 and GC-Fung, which amplify a suitable segment of SSU 18s rDNA for Denaturing Gradient Gel Electrophoresis (DGGE) analysis (May et al. 2001). PCR parameters were initial denaturation for $2 \mathrm{~min}$ at $94^{\circ} \mathrm{C}, 35$ amplification cycles of $94^{\circ} \mathrm{C}$ for 1 min denaturation, $1 \mathrm{~min}$ annealing at $50.3^{\circ} \mathrm{C}$, and $72^{\circ} \mathrm{C}$ for 1 min extension, and a final extension of $5 \mathrm{~min}$ at $72^{\circ} \mathrm{C}$. The amplification reaction mixture $(50 \mu \mathrm{L})$ included $200 \mu \mathrm{M}$ each DNTP, 3.5 $\mu \mathrm{M} \mathrm{MgCl}_{2}, 0.4 \mu \mathrm{M}$ of each primer, and one unit of taq DNA polymerase (GoTaq ${ }^{\circledR}$ Flexi DNA Polymerase, Promega). All amplifications were performed with an Eppendorf Mastercycler gradient thermocycler (Eppendorf $\AA$ ).

DNA from seawater was preamplified with fungal general primers NS1 and ITS4 (White et al. 1990). PCR parameters were adjusted to an initial denaturation of 2 min at $95^{\circ} \mathrm{C}, 30$ amplification cycles of $94^{\circ} \mathrm{C}$ for $1 \mathrm{~min}$ denaturation and $55^{\circ} \mathrm{C}$ for $4 \mathrm{~min}$ annealing/extension, and a final extension of $5 \mathrm{~min}$ at $72^{\circ} \mathrm{C}$. The reaction mixture was prepared as described earlier. One $\mu \mathrm{L}$ of the obtained amplifications products was subjected to standard PCR with NS1 and GC-Fung primers for DGGE analysis as previously described.
DENATURING GRADIENT GEL ELECTROPHORESIS

An $8 \%$ acrylamide/bisacrylamide $(37.5: 1)$ gel with a 20 $60 \%$ denaturing gradient $(1 \mathrm{~mm}$ thick, 1 xTAE buffer, $20 \mathrm{~cm}$ $\times 20 \mathrm{~cm}$ ) was used. Following polymerization, the gel was placed in the buffer chamber of a DCode Universal Mutation Detection System Unit (Bio-Rad) in 1xTAE buffer at $60^{\circ} \mathrm{C}$. PCR products $(\sim 40 \mu \mathrm{L})$ were loaded into the gel with $10 \mu \mathrm{L}$ of $2 x$ gel-loading dye and electrophoresis proceeded at $100 \mathrm{~V}$ and $60^{\circ} \mathrm{C}$ for $10 \mathrm{~h}$. The gel was stained in a $0.5 \mathrm{mg} \mathrm{L}^{-1} 1 \mathrm{x}$ TAE/ethidium bromide solution and photographed on a UV transilluminator. PCR products of Sacharomyces cerevisiae strain were used as positive control. Molecular richness was estimated as band number in each DGGE profile.

\section{FUNGAL ABUNDANCE}

Abundance of fungal hyphae in seawater was estimated by epifluorescence microscopy using an adaptation of the Calcofluor White stain method (Damare \& Raghukumar 2008, Cathrine \& Raghukumar 2009, Rasconi et al. 2009). Aliquots of 5 to $30 \mathrm{~mL}$ seawater were filtered on $0.22-\mu \mathrm{m}$ mesh black polycarbonate filters (Millipore Corp.). Filters with the retained material were stained directly with $600 \mu \mathrm{L}$ of aqueous $0.1 \%$ Calcofluor White, covering the complete filter area.

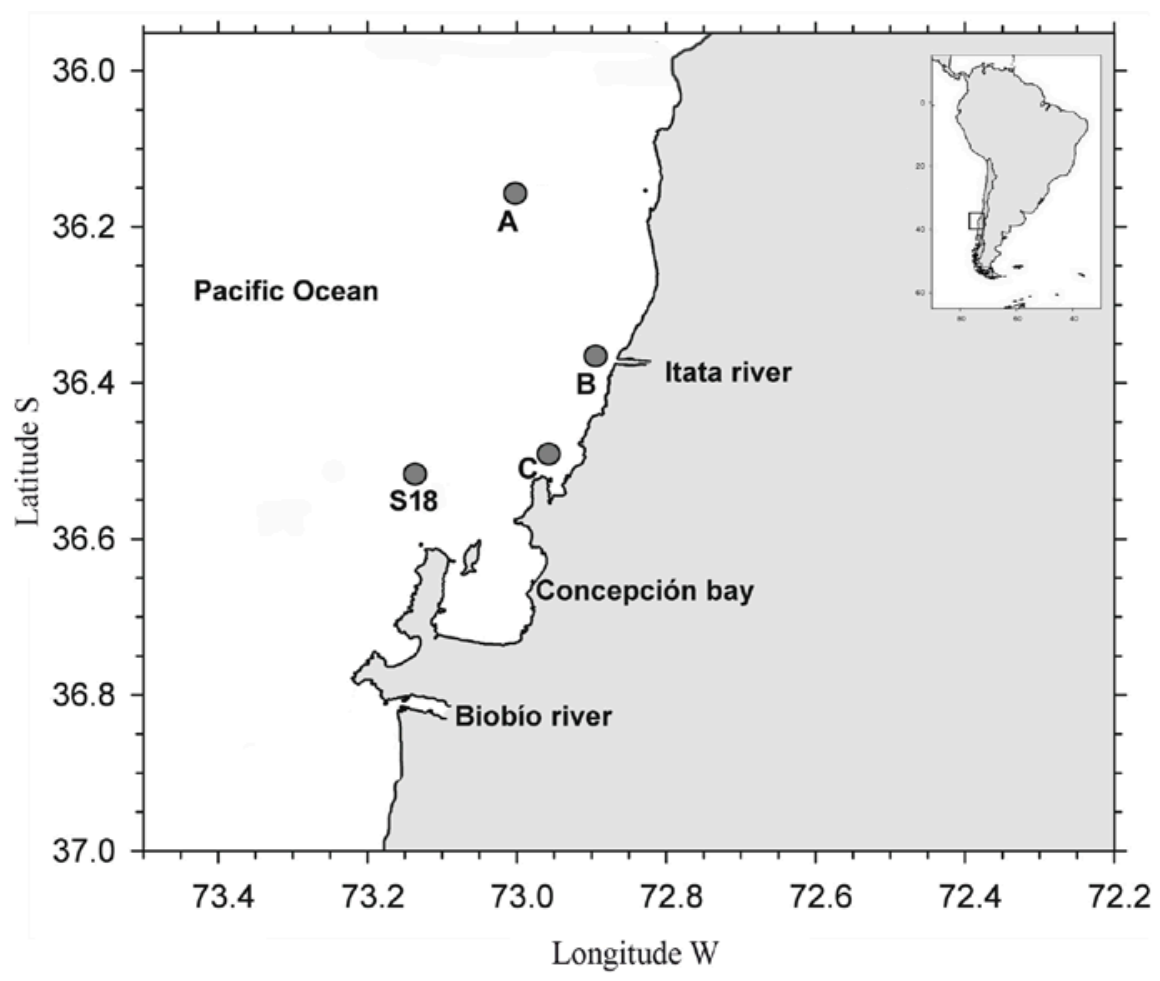

FIGURE 1. Location of the sampling stations in the area adjacent to the Itata river mouth (stations A, B, C) and at the COPAS Center Time Series Station 18.

FIGURA 1. Ubicación de las estaciones de muestreo en el área adyacente a la desembocadura del río Itata (estaciones A, B, C) y la Estación 18 de la Serie de Tiempo del Centro COPAS. 
The complete effective area of the filters was examined under an epifluorescence microscope (Axioscop 2 Plus, Carl Zeiss Ltd.) equipped with Filter set 49 (Carl Zeiss Ltd., 365 $\mathrm{nm}$ excitation and 445-450 $\mathrm{nm}$ emission band pass). The stained fungal filaments were recognized by the presence of septate hyphae, easily distinguishable from other filamentous materials such as detritus. All hyphae identified on the filters were counted at 1000X and their length and width recorded. Considering a tubular shape of hyphae, a cylinder volume was used as morphological approximation to estimate biovolume of fungal filaments (Cathrine \& Raghukumar 2009). Fungal carbon was estimated using the conversion factor $1 \mu \mathrm{m}^{3}=1 \mathrm{pg} \mathrm{C}$ (Van Veen \& Paul 1979). The average coefficient of variation for fungal carbon estimated for replicate samples was lower than $20 \%$.

\section{RESULTS AND DISCUSSION}

GENERAL

Saprotrophic fungi are the main degraders of plant detritus in terrestrial ecosystems (Carlile et al. 2001), and it is considered that they are better adapted than bacteria to acquiring nutrients in poor soil (De Boer et al. 2005). Fungi are also present in freshwater (e. g. Gulis et al. 2006) and have been detected in marine environments such as coastal waters (Gao et al. 2010), deep-sea sediments (Damare et al. 2006), hypersaline waters (Buchalo et al. 2000, Kis-Papo et al. 2003), methane hydrates (Lai et al. 2007), oxygen deficient ecosystems (Cathrine \& Raghukumar 2009), mangroves and salt marshes (Hyde et al. 1998, Raghukumar 2005), and hydrothermal vents (Le Calvez et al. 2009). Here, we demonstrate for the first time the presence of filamentous fungi in the coastal upwelling ecosystem off central Chile.

\section{MOLECULAR EVIDENCE OF FUNGI}

DNA from seawater and sediments of the area adjacent to the Itata river mouth showed positive amplifications of SSU 18s rDNA with specific fungal primers (Fig. 2a), evidencing the occurrence of filamentous fungi inhabiting waters and sediments of the coastal upwelling ecosystem off central south Chile.

The coastal upwelling ecosystem off Concepción is influenced by freshwater discharge from the Itata and Biobío rivers (Sobarzo et al. 2007), which may supply terrigenous organic matter to the coastal zone (Sánchez et al. 2009). Considering that fungi have been found to be responsible for degrading mainly terrigenous detritus in marine/terrestrial ecotones (Hyde et al. 1998, Raghukumar 2005), we associated the presence of fungi in our study area to the availability of terrestrial remains from rivers. In agreement with this idea, our results of molecular richness (Table 1), analyzed by DGGE, showed a higher number of fungal genotypes in surface waters ( $5 \mathrm{~m}$, Fig. 2b) and sediment (Fig. 2c) near the Itata river mouth and the coast (stations B, C) than in offshore areas (station A). Recently, a similar trend of higher molecular richness inshore than offshore, was shown by Gao et al. (2010) for waters off the Hawaiian coast.

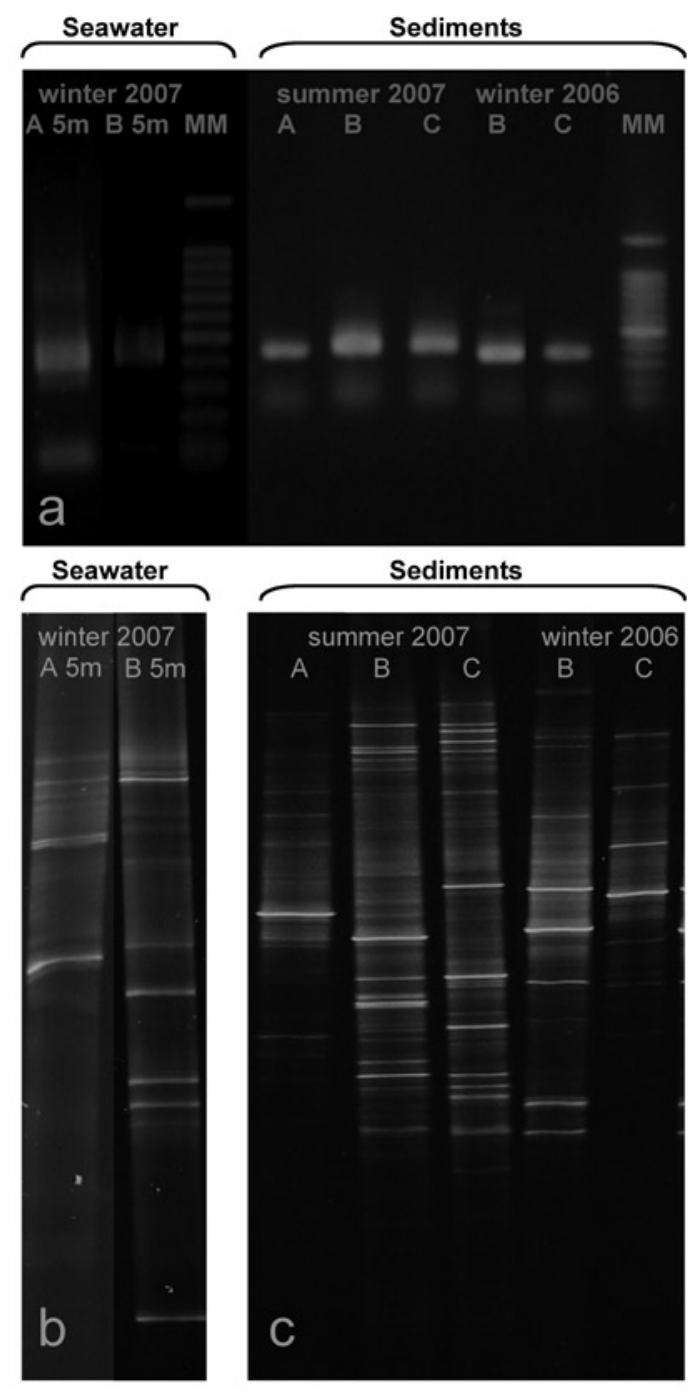

FIGURE 2. Positive PCR products for template rDNA extracted from surface seawater $(5 \mathrm{~m})$ and surface sediments (a) and denaturing gradient gel electrophoresis patterns in seawater (b) and sediments (c) for stations A, B and C in the area adjacent to the Itata river mouth.

FIGURA 2. Productos de PCR positivos desde rADN extraído de agua $(5 \mathrm{~m})$ y sedimento superficial (a) y patron de electroforesis en gel con gradiente denaturante en agua de mar (b) y sedimentos (c) para las estaciones A, B y C en el área adyacente a la desembocadura del río Itata. 
Since rivers could also discharge spores or remains of fungal tissues from freshwater and terrestrial environments (Kohlmeyer \& Kohlmeyer 1979) to the ocean, one could argue that the observed genotype patterns of fungi in coastal waters and sediments may include resistant propagules or surviving mycelium that have been transported to the marine environment. However, our results showed a higher number of molecular fungal types in sediments from stations $\mathrm{B}$ and $\mathrm{C}$ during the summer, when the Itata river flow is at its minimum
(Sánchez et al. 2009), than in winter (Table 2, Fig. 2b,c). The seasonal variability observed in the DGGE profiles of surface sediments suggests that warm conditions and the increment in marine organic matter available during the productive season, allow the development of a more diverse community of fungi. It has been found that environmental conditions and the availability of substrates in freshwater are the main factors triggering seasonal changes in fungal diversity, abundance, and activity (Gulis et al. 2006, Gessner et al. 2007).

TABLE 1. Molecular richness estimated as the number of bands from DGGE profiles (n.d. = not determined)

TABla 1. Riqueza molecular estimada a partir del número de bandas en los perfiles de DGGE (n.d. = no determinado)

\begin{tabular}{lcccc}
\hline & Station & Winter 2006 & Summer 2007 & Winter 2007 \\
\hline Surface waters & A & n.d. & n.d. & 6 \\
$(5 \mathrm{~m})$ & B & n.d. & n.d. & 10 \\
& & & & \\
Surface sediments & A & n.d. & 9 & n.d. \\
& B & 12 & 15 & n.d. \\
& C & 9 & 18 & n.d. \\
\hline
\end{tabular}

DETECTION OF FUNGI BY EPIFLUORESCENCE MICROSCOPY Direct observation of fungi retained on filters and stained with Calcofluor White revealed the presence of septate hyphae and spores (Fig. 3). The identified fungal filaments, ranging from 1 to $3 \mu \mathrm{m}$ in diameter and from 10 to $>200 \mu \mathrm{m}$ length, were observed as individual filaments or aggregates (Fig. 3) that could reach up to $20 \mu \mathrm{m}$ on diameter and over $50 \mu \mathrm{m}$ long, similar to fungi detected in deep-sea sediments in the Indian Basin (Damare \& Raghukumar 2008) and to waterstable aggregates associated to mycorrhizal fungi in soils ( $e$. g. Tisdall \& Oades 2006). Organic aggregates in the water column represent growth habitats for microorganism (Kiørboe \& Jackson 2001). Since fungi produce a wide range of extracellular enzymes to hydrolyze organic polymers (Carlile et al. 2001), the combined activity of fungi and prokaryotes in microbial hotspots could result in a highly efficient microbioreactor able to process particulate and dissolved organic matter during sedimentation of particles in the ocean.

It has been shown that both the transport of organic carbon to the sediment water interface and the sequestering of carbon in the ocean are influenced by marine snow formation (Azam \& Long 2001). Therefore, if the contribution of fungi to the formation of organic aggregates in the water column proves to be an ubiquitous phenomenon, they should be involved in the biogeochemical cycles of organic matter at macroscale.
VERTICAL DISTRIBUTION OF FUNGI IN THE WATER COLUMN Here we show, for the first time, vertical water column profiles of fungal biomass in the marine ecosystem. Fungal biomass ranged from 0.03 to $0.12 \mu \mathrm{g} \mathrm{C} \mathrm{L}^{-1}$ in the top $15 \mathrm{~m}$, decreasing toward bottom waters to values between 0.006 and $0.01 \mu \mathrm{g} \mathrm{C} \mathrm{L}^{-1}$ in Station A near the Itata river during the winter, and $\sim 6 \mu \mathrm{g} \mathrm{C} \mathrm{L}^{-1}$ at $7 \mathrm{~m}$ and between 0.19 and $0.44 \mu \mathrm{g}$ $\mathrm{C} \mathrm{L}^{-1}$ below $30 \mathrm{~m}$ at Station 18 during the summer (Fig. $4 \mathrm{a}$ ). Fungal biomass vertical structures (Fig. 4a) agree with those of chlorophyll- $a$ (Fig. 4b), with the general distribution of microplankton biomass in the ocean (e.g. Lalli \& Parsons 1996), and with the distribution of physical parameters of the water column (e. g. temperature and oxygen; Fig. 4c,d). This pattern suggests that fungi are active in the water column and respond, like most microbial heterotrophs, to the higher biological activity and organic matter availability in surface waters of the ocean during the productive season (summer).

Our findings show evidence of fungi in coastal upwelling ecosystem and suggest that fungal biomass and molecular richness vary seasonally in coastal waters off central Chile. We are currently investigating the implications of the presence of an active fungal community in the ocean on carbon cycling, as well as the role of fungi in the current paradigm of the microbial loop. 


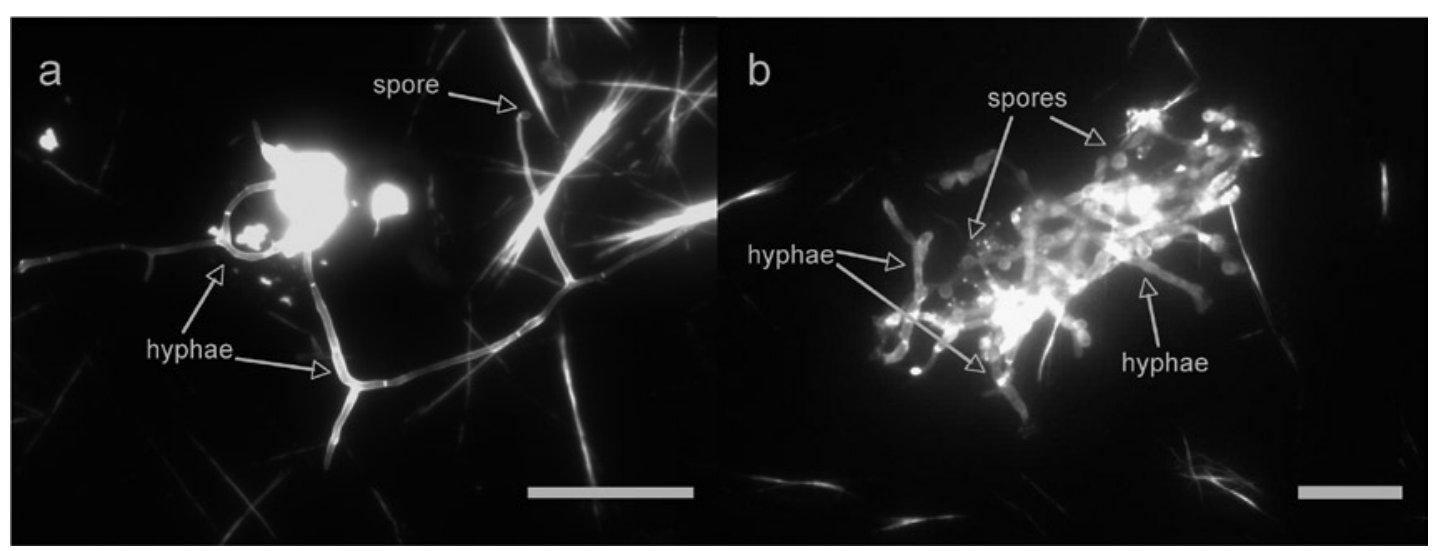

FIGURE 3. Filamentous fungi observed in the water column of Station A as single hyphae (a) and as aggregates (b). Scale bars correspond to $10 \mu \mathrm{m}$.

Figura 3. Hongos filamentosos observados en la columna de agua de la Estación A, como hifas individuales (a) y agregados (b). La barra corresponde a $10 \mu \mathrm{m}$.

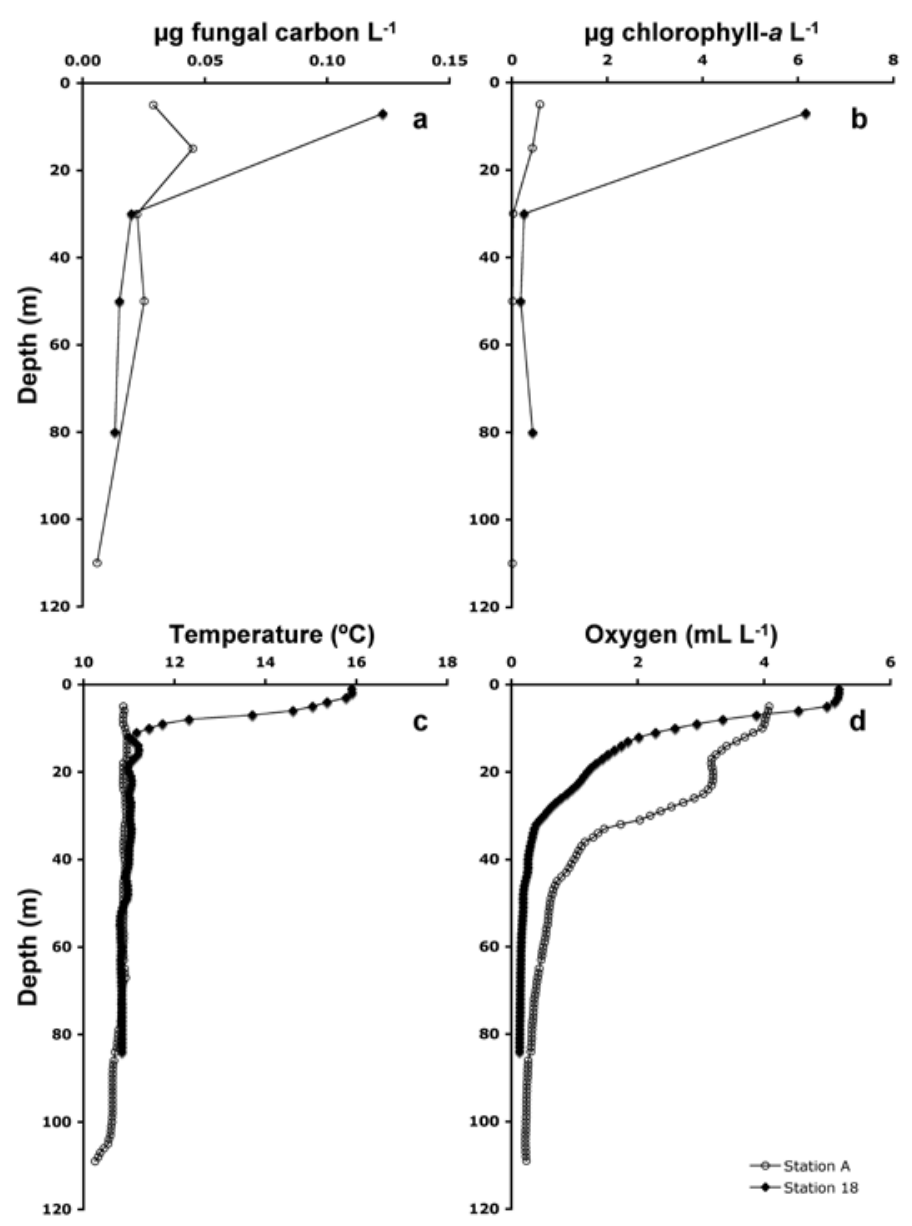

FIGURE 4. Vertical profiles of fungal biomass (a), chlorophyll- $a$ (b), temperature (c) and oxygen (c) in station A during austral Winter 2007 and in station 18 during austral Summer 2008.

Figura 4. Perfiles verticales de biomasa de hongos (a), clorofila- $a$ (b), temperatura (c) y oxígeno (d) en la estación A durante el invierno austral de 2007 y en la estación 18 durante el verano austral de 2008. 


\section{ACKNOWLEDGMENTS}

We thank E. Tejos, for his valuable help during field and laboratory work. This research was funded by the Programa de Investigación Marina de Excelencia Pimex-Nueva Aldea (Universidad de Concepción) funded by Celulosa Arauco y Constitución S. A., and partially by the COPAS Center (Project $\mathrm{N}^{\circ}$ 150100007). We are thankful to the COPAS Time Series team, the R/V Kay Kay II crew for their valuable help during field work and the reviewers for their valuable comments.

\section{BIBLIOGRAPHY}

AzAm, F. \& A.A. Long. 2001. Sea snow microcosms. Nature. 414: 495-498.

Buchalo, A.S., E. Nevo, S.P. Wasser \& P.A. Volz. 2000. Newly discovered halophilic fungi in the Dead Sea (Israel). En: Journey to diverse microbial worlds (Ed. Seckbach, J.), p 239-252. Kluwer, Dordrecht, The Netherlands.

CÁceres, M. \& D.F. Arcos. 1991. Variabilidad en la estructura espacio-temporal de un área de surgencia frente a la costa de Concepción, Chile. Investigación Pesquera (Chile) 36: 27-38.

Cathrine, S.J. \& C. Raghukumar. 2009. Anaerobic denitrification in fungi from the coastal marine sediments off Goa, India. Mycological Research 113: 100-109.

Carlile, M.J., S.C. Watkinson \& G.W. Gooday. 2001. The fungi, 2nd edn. Academic Press, San Diego. 558 pp.

Clipson, N., M. Otte \& E. Landy. 2006. Biogeochemical roles of fungi in the marine and estuarine habitats. En: Fungi in biogeochemical cycle (Ed. Gadd, G.M.), pp 436-461. Cambridge University Press, New York.

Cuevas, L.A., G. Daneri, B. JacoB \& P. Montero. 2004. Microbial abundance and activity in the seasonal upwelling area off Concepción $\left(36^{\circ} \mathrm{S}\right)$, central Chile: a comparison of upwelling and non-upwelling conditions. Deep-Sea Research Part II 51: 2427-2440.

Damare, S. \& C. Raghukumar. 2008. Fungi and macroaggregation in deep-sea sediments. Microbial Ecology 56:168-177.

Damare, S., Raghukumar, C. \& Raghukumar, S. 2006. Fungi in deep-sea sediments of the Central Indian Basin. Deep-Sea Research Part I 53:14-27.

Daneri, G., V. Dellarossa, R. Quiñones, B. Jacob, P. Montero \& O. UlloA. 2000. Primary production and community respiration in the Humboldt Current System off Chile and associated oceanic areas. Marine Ecology Progress Series 197: 41-49.

De Boer, W., L.B. Folman, R.C. Summerbell \& L. Boddy. 2005. Living in a fungal world: impact of fungi on soil bacterial niche development. FEMS Microbiology Reviews 29: 795-811.

Fell, J.W. \& S.Y. Newell. 1998. Biochemical and molecular methods for the study of marine fungi. En: Biochemical and molecular methods for the study of marine fungi (Ed. Cooksey, K.E.), pp 259-283. Chapman and Hall, London.

Figueroa, A.D. \& C. Moffat. 2000. On the influence of topography in the induction of coastal upwelling along the Chilean coast. Geophysical Research Letters 27: 3905-3908.

GAO, Z., Z.I. JOHNSON \& G. WANG. 2010. Molecular characterization of the spatial diversity and novel lineages of mycoplankton in Hawaiian coastal waters. The ISME Journal 4: 111-120.

Gessner, M.O., V. Gulis, K.A. Kuehn, E. Chauvet \& K. Suberkropp. 2007. Fungal decomposers of plant litter in aquatic ecosystems. In: The Mycota, Vol. IV, Environmental and Microbial Relationships (Eds. Kubicek, C.P. \& Druzhinina, I.S.) 2nd edn., p 301-324. Springer, Berlin.

González, H.E., G. Daneri, D. Figueroa, L. Iriarte, N. Lefevre, G. Pizarro, R.A. Quiñones, M. Sobarzo \& A. Troncoso. 1998. Producción primaria y su destino en la trama trófica pelágica y océano profundo e intercambio océano-atmósfera de $\mathrm{CO}_{2}$ en la zona norte de la corriente de Humboldt $\left(23^{\circ} \mathrm{S}\right)$ : posibles efectos del evento El Niño 1997-1998. Revista Chilena de Historia Natural 71: 429-458.

Gulis, V., K. Kuehn \& K. Suberkropp. 2006. The role of fungi in carbon and nitrogen cycles in freshwater ecosystems. In: Fungi in biogeochemical cycles (Ed. Gadd, G.M.) , pp 405-435. Cambridge University Press, New York.

Hyde, K., Jones, E.B.G., Leaño, E., Pointing, S., Poonyth, A.D. \& L. VRIJMOED. 1998. Role of fungi in marine ecosystem. Biodiversity and Conservation 7: 1147-1161.

Kohlmeyer, J. \& E. Kohlmeyer. 1979. Marine mycology, the higher fungi. Academic Press, New York. 690 pp.

Kis-Papo, T., A. Oren, S.P. Wasser \& E. Nevo. 2003. Survival of Filamentous Fungi in Hypersaline Dead Sea Water. Microbial Ecology 45: 183-190.

Kiørboe, T. \& G.A. JaCKSON. 2001. Marine snow, organic solute plumes, and optimal chemosensory behavior of bacteria. Limnology and Oceanography 46: 1309-1318.

Lai, X., L. CaO, H. Tan, S. Fang, Y. Huang \& S. Zhou. 2007. Fungal communities from methane hydrate-bearing deepsea marine sediments in South China Sea. The ISME Journal 1: 756-762.

Lalli, C.M. \& T.R. Parsons. 1996. Biological Oceanography: An Introduction. Butterworth/Heinemann, Oxford. $320 \mathrm{pp}$.

Le Calvez, T., G. Burgaud, S. Mahé, G. Barbier \& P. VANDENKOORNHUYSE. 2009. Fungal diversity in deep-sea hydrothermal ecosystem. Applied and Environmental Microbiology 75: 6415-6421.

LEVIPÁN, H.A., R.A. QUiÑones \& H. URRUTIA. 2007. A time series of prokaryote secondary production in the oxygen minimum zone of the Humboldt current system, off central Chile. Progress in Oceanography 75: 531-549.

May, L.A., B. Smiley \& M.G. Schmidt. 2001. Comparative denaturing gradient gel electrophoresis analysis of fungal communities associated with whole plant corn silage. Canadian Journal Microbiology 47: 829-841.

Montero, P., G. Daneri, L.A. Cuevas, H.E. GonzÁlez, B. Jacob, L. LizÁRraga \& E. Menschel. 2007. Productivity cycles in the coastal upwelling area off Concepción: the importance of diatoms and bacterioplankton in the organic carbon flux. Progress in Oceanography 75: 518-530.

Parsons, T., Y. Maita \& C. LaLli. 1984. A manual of chemical and biological method for seawater analysis. Pergamon Press, Great Britain. 173 pp.

Quiñones, R.A. \& R. Montes. 2001. Relationship between freshwater input to the coastal zone and the historical 
Fungi in the coastal upwelling ecosystem off Chile: MARCELo GutiérReZ eT AL.

landings of the benthic/demersal fish Eleginops maclovinus in central-south Chile. Fisheries Oceanography 10: 311328.

QuiÑones, R.A., H.A. LeVIPÁn \& H. UrRutia. 2009. Spatial and temporal variability of planktonic archaeal abundance in the Humboldt Current System off Chile. Deep-Sea Research Part II 56: 1073-1082.

Raghukumar, S. 2005. The Role of Fungi in Marine Detrital Processes. En: Marine Microbiology: Facets \& Opportunities (Ed. Ramaiah N.), pp 91-101. National Institute of Oceanography, Goa, India.

Rasconi, S., M. Jobard, L. Jouve \& T. Sime-Ngando. 2009. Use of calcofluor white for detection, identification, and quantification of phytoplanktonic fungal parasites. Applied and Environmental Microbiology 75: 25452553.

Sánchez, G.E., S. Pantoja, C.B. Lange, H.E. GonzÁlez \& G. DANERI. 2008. Seasonal changes in particulate biogenic and lithogenic silica in the upwelling system off Concepción $\left(\sim 36^{\circ} \mathrm{S}\right)$, Chile, and their relationship to fluctuations in marine productivity and continental input. Continental Shelf Research 28: 2594-2600.

Sobarzo, M., L. Bravo, D. Donoso, J. Garcés-Vargas \& W. SCHNEIDER. 2007. Coastal upwelling and seasonal cycles that influence the water column over the continental shelf off central Chile. Progress in Oceanography 75: 363-382.
Strub, P.T., J. Mesias, V. Montecino, J. Rutllant \& S. Salinas. 1998. Coastal ocean circulation off western South America, Coastal Segment (6,E). En: The Sea, vol. 11 (Eds. Robinson, A., Brink, K.), pp 273-313. John Wiley $\&$ Sons, New York.

Tisdall, J.M. \& J.M. OADES. 2006. Organic matter and water-stable aggregates in soils. European Journal of Soil Science 33: 141-163.

Troncoso, V.A., G. Daneri, L.A. Cuevas, B. Jacob \& P. Montero 2003. Bacterial carbon flow in the Humboldt Current System off Chile. Marine Ecology Progress Series 250: $1-12$.

Van Veen, J.A. \& E.A. Paul 1979. Conversion of biovolume measurements of soil organisms, grown under various moisture tensions, to biomass and their nutrient content. Applied and Environmental Microbiology 37: 686-692.

White, T.J., T.D. Bruns, S.B. LeE \& J.W. TaYlor 1990. Analysis of phylogenetic relationships by amplification and direct sequencing of ribosomal DNA genes. En: PCR protocols: A Guide to Methods and Applications (Eds. Innis, M.A., Gelfand, D.H., Sninsky, J.J. \& White, T.J.), pp 315-322. Academic Press, San Diego.

Wong, M.K.M., T-K. Goh, I.J. Hodgkiss, K.D. Hyde, V.M. Ranghoo, C.K.M. Tsui, W-H. Ho, W.S.W. Wong, TK. YuEN. 1998. Role of fungi in freshwater ecosystems. Biodiversity and Conservation 7: 1187-1206. 